\title{
Agri-environmental measures and the breeding ecology of a declining farmland bird
}

by McHugh, N.M., Prior, M., Grice, P.V., Leather, S.R., Holland, J.H.

Copyright, Publisher and Additional Information: This is the author accepted manuscript. The final published version (version of record) is available online via ScienceDirect

Please refer to any applicable terms of use of the publisher.

DOI: $\underline{\text { https://doi.org/10.1016/j.biocon.2017.06.023 }}$ 


\section{Agri-environmental measures and the breeding ecology of a declining \\ 2 farmland bird}

3

4 Niamh M. McHugh 1,2*, Matt Prior ${ }^{3}$, Philip V. Grice ${ }^{4}$, Simon R. Leather ${ }^{5}$, John M. Holland ${ }^{2}$

5 1. Silwood Park Campus, Imperial College London, Buckhurst Road, Ascot, Berkshire, $6 \quad$ SL5 7PY, UK

7 2. Game and Wildlife Conservation Trust, Fordingbridge, Hampshire, SP6 1EF, UK

8 3. Wiltshire Ornithological Society, 1 Rother Close, Greenmeadow, Swindon, Wiltshire, SN25 3PZ, UK

4. Natural England, County Hall, Spetchley Road, Worcester, WR5 2NP, UK

5. Crop and Environmental Sciences, Harper Adams University, Newport, TF10 8NB, UK

\section{Abstract}

Agricultural intensification is a key cause of the population declines shown by many farmland bird species across Europe. Changes in land management through agri-environment schemes (AES) are frequently cited as the best tool to reverse these trends, to date however they have received mixed support. This study tested whether AES options in England that provide winter seed food or insect-rich foraging during the breeding season, were associated with improved breeding performance in tree sparrow, Passer montanus, and/or the formation of larger breeding colonies. Breeding attempts $(n=428)$ representing 210 pairs of tree sparrow comprising 22 colonies were compared in Wiltshire, England in 2013 and 2014. The area of 
margin AES, an insect-rich habitat, was positively correlated with fledgling success per

27 breeding attempt and per breeding pair. Colony size increased with increasing wild bird seed mix AES area, a winter seed food resource, but this option negatively affected hatching success and the number of fledglings produced per breeding attempt. The observed association between colony size and this habitat was expected given that wild bird seed mixtures provide important seed food resources for granivorous birds during winter. The negative correlation with fledgling success, on the other hand, requires further investigation to determine whether this relationship relates to a lack of invertebrate and seed food during

34 the breeding period. These results highlight the importance of providing a suite of AES

35 habitats that are appropriately located to deliver both overwintering and breeding requirements of target, declining farmland birds.

\section{Keywords}

39 Farmland birds; Common Agricultural Policy; Insect; Conservation; Agro-ecology 


\section{Introduction}

41 Changes in agricultural practices across Europe and North America, have, over the last four

42 decades resulted in habitat destruction, fragmentation, and degradation which have been

43 linked to farmland bird declines across these regions (Askins, 1999; Donald et al., 2006;

44 Murphy, 2003). These changes included field enlargement through hedgerow removal reducing the availability of suitable nesting and foraging habitats for many species, the use of more efficient farm machinery (leading to less spilled grain) and reduced areas of uncropped land (important as a foraging, roosting and nesting habitat; Sotherton and Self, 2000; Marshall and Moonen 2002; Newton 2004; Tscharntke et al, 2005). In addition, changes in crop management have reduced bird food supplies, for example, the more extensive use of inorganic herbicides and pesticides has removed weeds and their associated invertebrates and a switch to autumn sown crops means over-winter stubbles have become less common (Newton, 2004; Tscharntke et al, 2005). These changes, have in turn allowed changes in extent and diversity of crops (e.g. loss of oats and growth in oilseed rape), and to regional specialisation in agriculture (leading to a loss of traditional, rotational mixed farming in many areas). Consequently, birds associated with agricultural landscapes have fewer places to nest, raise fewer offspring and have poorer overwinter survival (Newton, 2004). These aspects of agricultural intensification occurred concurrently, making it hard to isolate their individual impacts (Newton, 2004), but collectively they have contributed to the simplification of farmland ecosystems (Matson et al. 1997; Tscharntke et al. 2005).

61 The reduced availability of key resources has been linked to severe farmland bird population

62 declines and on average the abundance of common farmland birds has halved since 1980

63 (Voříšek et al., 2005). Across Europe farmland bird declines are considered a high 
conservation priority and Agri-Environment Schemes (AES) have been the main policy mechanism adopted for addressing these concerns (Donald et al., 2006). In England AES have attempted to help improve habitat heterogeneity by creating or restoring habitats focused on providing food to aid over-winter survival and also to help ensure both chick food and nesting habitat are plentiful over the breeding season (Natural England, 2013a, 2013b).

Associations between farmland birds and AES habitats have been used by a wide number of studies across Europe in an attempt to evaluate their success (e.g. Burgess et al., 2014; Bright et al., 2015; Davey et al., 2010a,b; Douglas et al., 2009; Gilroy et al., 2009; Kleijn et al., 2001; Princé et al., 2012; Wilson, 2001). Studies have defined AES success in terms of their impact on bird density and use of AES habitats while foraging. Current studies however, lack information on potential mechanisms for such relationships i.e. habitat accessibility and/or improved invertebrate chick-food supplies (but see McHugh et al. 2016a). Insufficient chick food is known to reduce breeding success of grey partridge Perdix perdix, Eurasian skylark Alauda arvensis, corn bunting Emberiza calandra and yellowhammer Emberiza citrinella (Brickle et al., 2000; Boatman et al., 2004; Potts, 2012) and, may also impact other farmland birds whose chicks are provisioned largely with invertebrates when in the nest (Newton, 2004). The abundance of invertebrates has also been impacted by modern agricultural practices; for example, the abundance of grey partridge chick-food taxa on the Sussex Downs, where annual monitoring has taken place since 1969, show an overall downward trend in abundance and are thought to be representative of the situation on a national scale (Potts, 2012). Indeed, the grey partridge chick food index, the only measure available that relates chick-food abundance to chick-survival, was below the level necessary to sustain a population of grey partridge in all arable crops in the study area (Potts, 2012). 
89 The central aim of this paper is to document whether the productivity of a hole-nesting

90 granivorous farmland bird, the tree sparrow Passer montanus, whose chicks are dependent on

91 invertebrate food resources, is limited by the availability of invertebrate-rich foraging habitat.

92 In the United Kingdom over a 31 year period tree sparrows have suffered a decline of over

93

94 97\% (BTO, 2015). When breeding, tree sparrows can adapt their foraging radius to prey densities and conspecifics, but have been found to forage within an average distance of $200 \mathrm{~m}$ from their nests (Deckert, 1962; Summer-Smith, 1995). Here, we tested whether colony size, total productivity and per-attempt productivity in tree sparrows was linked to the area of different agricultural habitats, including those provided by AES, within $200 \mathrm{~m}$ of their nest boxes. We predicted that higher fledgling success may be more frequently associated with habitats that are rich in chick food invertebrates such as margin AES (Vickery et al., 2002) due to the dependence of chicks on invertebrate food resources. We expected that fledgling success would be negatively affected by the habitat wild bird seed mixture (WBSM) as this habitat is aimed at winter seed food provision, and annual mixes are thought to be a poor source of chick-food resources (McHugh et al., 2016b). Additionally, we examine probable causes for these relationships by comparing tree sparrow chick food abundance in the available agricultural habitat types. Finally, breeding success-habitat area relationships may relate to density dependence mechanisms (Pärn et al., 2011; Ringsby et al., 2002; Svensson et al., 2006), influencing competition for available chick-food resources, therefore we investigated the relationship between tree sparrow colony size and breeding success.

\section{Methods}

\subsection{Study area}


Data collection took place in the south of England, in the mixed farming landscape of the Marlborough and Pewsley Downs, within the North Wessex Downs Area of Outstanding Natural Beauty (AONB). The study is centred around 51.42, -1.84 WGS $84.84 \%$ of this land is used for agricultural production and the principal land use (over 60\%) is arable farming (AONB, 2014). The study sites under investigation were conventionally farmed and form part of a long-term tree sparrow monitoring project run by the Wiltshire Ornithology Society (WOS). It is important to note that the number of nest boxes was uneven across sites. As colony size increases, more nest boxes are provided by WOS and none of the sites had reached capacity. This ensures that nest box availability is not a factor limiting colony size.

Within and between each of the 11 farm sites, groups of nest boxes that were separated by more than $400 \mathrm{~m}$ were defined as separate sampling units, resulting in 22 discrete tree sparrow colonies (Figure 1). The maximum distance between neighbouring nest boxes was $253 \mathrm{~m}$ $(49.46 \pm 10.54 \mathrm{~m})$ and minimum distance was $0.49 \mathrm{~m}(3.50 \pm 0.76 \mathrm{~m})$. All habitat types found within $200 \mathrm{~m}$ of colonies were mapped using farm maps received from farmers and through on-site verification. Individual nest box data was later extracted and analysed. $200 \mathrm{~m}$ was chosen as the area adult tree sparrows were most likely to forage within when collecting insects to feed chicks. Habitat data was digitised using ArcMap GIS v. 10.2. 200m was chosen as the area adult tree sparrows were most likely to forage within when collecting insects to feed chicks (Deckert, 1962; Summers-Smith, 1995; McHugh et al., 2016b; Zhang and Zheng, 2010). Nest boxes with overlapping 200m buffers were classified as members of the same tree sparrow colony. Individual nest box data was later extracted and analysed. 
The habitat types present on these farms included permanent and temporary grassland; arable crops (cereals: barley, Hordeum, and wheat, Triticum; broadleaf crops: oilseed rape, Brassica napus spp.). AES margin (an aggregate group of structurally similar grassy semi-natural habitats, and includes grass buffers, uncropped field corners, floristically enhanced margins, and pollen and nectar mix. Note: non-AES grass habitats, such as grazed grassland, were exceluded from this category); wild bird seed mixture (plots sown with seed rich plants to provide seed to granivorous farmland birds over winter; WBSM) and woodland habitats. To increase statistical power for analysis, these habitats were classified into 11 groups according to structural and functional similarities (Table A1).

\subsection{Productivity Data}

This study was conducted over two consecutive years, 2013 and 2014, during the tree sparrow breeding season (April to August). Nest boxes were checked every 2-3 days to obtain the following basic reproductive parameters; clutch size, total eggs (per pair), hatching success (proportion of hatched eggs), number of fledglings, fledging success (proportion of hatchlings that resulted in fledglings) and the number of breeding attempts. This resulted in two productivity datasets 1) total productivity data where breeding measurements were pooled for pairs of birds across the breeding season and 2) per-attempt productivity data, where individual breeding attempts were investigated.

Tree sparrows have multiple clutches per pair per year; the assignment of chicks to a brood category (1st, 2 nd or $3 \mathrm{rd}$ ) is based on three assumptions: 1 . Consecutive clutches laid in the same nest box belong to the same pair, 2. Pairs do not change nests for successive broods and 3. Clutches laid in new boxes after the end of May were assumed to be second broods $(n=13)$ 
and after mid-July were assumed to be third broods ( $\mathrm{n}=3$ ). Deckert (1962) and SummerSmith (1995) suggest that these assumptions are largely valid, although during their behavioural studies, colour ringed birds were occasionally found to use more than one nest site.

\subsection{Invertebrate Monitoring in Agricultural Habitats}

Between the 9th and 24th July 2013, two sweep net samples were taken from permanent and temporary grassland, grass buffer strips, floristically enhanced margins, pollen and nectar margins, uncropped field corners, oilseed rape, spring wheat, spring barley, wild bird seed mixture (WBSM), winter wheat and winter barley $(n=178)$. For the purpose of analysis these habitats were grouped into six broader categories representing structurally or functionally similar habitat types (Table A.1). Where more than one replicate of a component habitat was available to a colony the replicate to be sampled was randomly chosen using R. Random points within these habitats were chosen as sampling locations using ArcGIS v10.3. Samples comprised ten 180 degree sweeps, covering a distance of approximately $10 \mathrm{~m}$. There are however, some limitations relating to this method including the variance in sampling efficiency relating to habitat type sampled and variation in the species recorded depending on their vertical distribution (Southwood, 1987).

\subsection{Data Analysis}

Data exploration and statistical analysis was conducted in Rv3.03 (R Core Development Team, 2014). The data were explored using the procedure outlined by Zuur et al. (2010). Dotplots together with histograms were used to determine whether transformations of 
covariates were necessary. This led to the use of the ArcSine square-root transformation on habitat area variables.

Pearson correlation coefficients $(<-0.5$ and $>0.5)$ and Variance Inflation Factors (VIFs; $>3$ ) were used to remove correlated variables (Ieno and Zurr, 2015). Pearsons correlation was highest between winter cereal and oilseed rape ( -0.56 for all datasets) resulting in VIFs $>10$ for grassland (in per-attempt productivity data), spring cereal (in all datasets), winter cereal (in all datasets), and oilseed rape (in all datasets). By excluding winter cereal from datasets, VIFs for all variables were reduced to an acceptable level, below 3 (Ieno and Zurr, 2015). The spread of the data was investigated using Cleveland dotplots and led to the exclusion of spring cereal, water and other arable from analysis as these habitats were present on land surrounding $<5 \%$ of occupied nest boxes.

For our colony size-habitat area model, colony size was modelled against the average area of each habitat within $200 \mathrm{~m}$ of tree sparrow nestboxes in each colony and year, in a quasipoisson distributed generalised linear model (GLM; Table 1). Only permanent habitat variables (boundary, farmyard buildings, grassland, margin AES, woodland and WBSM) were included in our full model as they are present before tree sparrows establish their breeding territories. The model was simplified via backward stepwise selection (Crawley, 2012). Model assumptions were tested using diagnostic plots from the package lme4.

Backward stepwise selection of explanatory variables from Generalised Linear Mixed Effects Models (GLMMs) was conducted to model total productivity per pair, per-attempt productivity and tree sparrow chick food invertebrate abundance (Table 1). Tree sparrow 
chick food abundance was calculated, using our sweep net data, as the sum of food items representing $>5 \%$ of chick diet and was composed of Araneae, Coleoptera, coleopteran larvae, Diptera, Lepidoptera larvae and Tipulidae (McHugh et al., 2016b). For the chick food abundance model, a full model was fitted to model invertebrate abundance and habitat types. Sampled habitats were grouped into six broad categories representing structurally or functionally similar habitat types; grassland, margin AES, oilseed rape, spring cereal, WBSM and winter cereal (Table A.1). Wald Z-tests were used to measure the influence of independent variables that were included in models as fixed effects (Aebischer et al., 2014). The most complicated models that could be fitted to the data contained eight additive fixed convergence.

GLMM model overdispersion was investigated by calculating the sum of squared Pearson's residuals, divided by the number of observations, minus the number of parameters. A dispersion statistic greater than 1 indicates model overdispersion, our GLMM models were not found to be overdispersed. Model assumptions were tested through diagnostic plots produced with the package ggplot2 (Wickham, 2009) and model prediction plots were produced using the effects package (Fox, 2003).

Density dependence was examined by modelling mean clutch size, hatching success, number of fledglings and fledgling success per colony against colony size, whilst accounting for seasonality by including year and brood as fixed effects in GLMs (Table 1). Where appropriate quasibinomial and quasipoisson distributions were used to account for model overdispersion, model assumptions were checked using the plot function in the lme4 package. 


\section{Results}

\subsection{Colony size}

233

22 colonies were monitored in total (19 were active in 2013 and 18 in 2014), consequently productivity data for 7 colonies were only collected in one of the two years. Colonies ranged in size from 1 to 24 pairs in both years (mean $5.47 \pm 1.26$ in 2013 and $6 \pm 1.41$ in 2014), with a total of 104 actively breeding pairs in 2013 and 106 in 2014, and 428 breeding attempts over the two-year period.

Colony size increased significantly with the area of WBSM present and decreased in relation to increasing grassland area (Table 2; Figure 2).

\subsection{Total productivity per pair}

243 Between 1 and 3 breeding attempts per pair were made per year (April to August). We found 244 no effect of habitat area variables on the number of broods produced per pair.

246 The mean total number of eggs produced by a breeding pair was $10.31 \pm 1.02$ in 2013 and $24712.25 \pm 1.19$ in 2014. According to our Minimum Adequate Model (MAM; Table 2), the 248 predicted total number of eggs produced by a pair over the breeding season decreased with 249 the area of woodland. 
In $20137.91 \pm 0.77$ chicks hatched compared with $9.92 \pm 0.96$ in 2014 . Hatching success

252

253

254

255

256

257

258

259

260

261

262

263

264

265

266

267

268

269

270

271

272

273

decreased relative to the areas of margin AES, WBSM, grassland and woodland available and increased relative to the area farmyard building area coverage (Table 2).

An average of $5.96 \pm 0.59$ chicks successfully fledged in 2013 compared to $9.1 \pm 0.88$ in 2014. The MAM for fledgling success per pair showed that over the breeding season the fledgling success increased relative to margin AES, oilseed rape, boundary and farmyard buildings area coverage (Table 2; Figure 3).

\subsection{Per-attempt productivity}

The mean clutch size was $5.44 \pm 0.38$ in 2013 and $5.60 \pm 0.29$ in 2014 . There was no evidence of a relationship between clutch size per-breeding attempt and habitat variables as our MAM was the null model.

Tree sparrows hatched an average of $4.15 \pm 0.29$ and $4.53 \pm 0.29$ chicks per breeding attempt in 2013 and 2014, respectively. Estimates from our model of tree sparrow hatching success per-attempt suggest that success significantly decreased with the area of margin AES, WBSM, grassland and woodland, and increased with the area of farmyard buildings (Table 2).

The number of fledglings per-attempt in 2013 was $3.13 \pm 0.22$ and $4.15 \pm 0.11$ in 2014. The MAM showed that fledging success increased as the areas of boundary, margin AES, oilseed rape, habitat and farmyard buildings increased but was reduced with increased woodland 
coverage (Table 2). Fledgling success was higher in second and third broods when compared to first broods. The number of fledglings per-attempt, however, was negatively correlated with the area of WBSM and woodland surrounding nest boxes and positively correlated with the area of oilseed rape. The number of fledglings was higher in second broods when compared to first broods.

\subsection{Chick food abundance in agricultural habitats}

Tree sparrow chick food abundance was significantly higher in margin AES when compared with spring cereal $(\mathrm{z}=-3.85, \mathrm{p}<0.001)$, winter cereal $(\mathrm{z}=-6.60, \mathrm{p}<0.001)$ and $\operatorname{WBSM}(\mathrm{z}=$ $2.25, \mathrm{p}<0.05)$, but no significant difference between margin AES and oilseed rape $(\mathrm{z}=-1.05$, $\mathrm{p}=0.29)$ or grassland $(\mathrm{z}=-1.03, \mathrm{p}=0.31 ;$ Figure 4$)$.

\subsection{Density Dependence}

The average clutch size, hatching success, number of fledglings and fledgling success per breeding attempt showed no significant relationship with colony size (Table B1).

\section{Discussion}

This study explored tree sparrow habitat associations and productivity over the nesting period in relation to the provision of key resources by AES options. For passerines, previous studies have shown that poorer breeding success was found where invertebrate abundance had been reduced through agricultural intensification (Bradbury and Stoate, 2000; Brickle et al., 2000; Hart et al., 2006). For that reason, our finding that fledging success (in total productivity and per-attempt models) increased with the area of AES margin, confirmed that these AES 
habitats benefitted tree sparrows. In addition, we demonstrated that the abundance of foliar tree sparrow chick food was significantly higher in this habitat, highlighting the potential role AES margins can play in chick food provisioning. The value of AES margins to farmland biodiversity has been widely studied (Vickery et al, 2009) with studies from the United Kingdom demonstrating that grass margins are heavily exploited by a variety of species including yellowhammer, corn bunting and skylark while provisioning nestlings (Brickle and Harper, 2000; Morris et al., 2001; Douglas et al., 2009). These habitats however, do not always contain appropriate chick food levels for other farmland birds. Holland et al., (2014) found that flower-rich AES habitats contain high levels of grey partridge chick food, but levels of general chick food were no higher than in other commonly found AES habitats. Consequently, given the variation in chick food requirements and foraging strategies (Holland et al., 2006), a range of habitats offering different invertebrate resources and of varying vegetation structure is likely to be needed to adequately provide for a suite of farmland birds. The finding that margin AES habitats had a negative influence on hatching success, is however more difficult to explain. It may be that as this habitat is a poor source of seed resources for granivorous adults it therefore does not help adults reach breeding condition.

We identified a positive relationship between fledging success (in total productivity and perattempt models) and farmyard buildings, in addition to the number of fledglings per-attempt and farmyard buildings. These relationships may reflect the role of farmyards in providing spilt grain or livestock feed which might influence the distribution or density of pairs (Gillings et al., 2005; Lack, 1995). Alternatively, untidy yards and buildings with areas of grass, common nettles Urtica dioica or European elder Sambucus nigra may increase chick food resources. Interestingly Gillings et al., (2005) found that a range of other granivorous 
species including house sparrow Passer domesticus, common chaffinch Fringilla coelebs and greenfinch Carduelis chloris, are positively associated with farmyard availability. It is important to note that sites were excluded from the study where nest boxes were located on houses or where housing and gardens fell within the absolute foraging range of a colony. This was done to remove the influence of garden feeders on analysis and ensure the results reflected a truly farmland environment.

Field and Anderson (2004) suggested that tree sparrow colonies utilise winter seed food resources, a finding that is confirmed by this study as colony size was shown to increase with the area of WBSM. Provision of seed food over winter has also resulted in higher breeding densities of other granivorous species (Hole et al., 2002; Robinson et al., 2002; Siriwardena et al., 2007). However, despite the importance of WBSM over winter, our results point to a negative relationship between two measures of breeding success: hatching success perattempt and the number of fledglings produced per breeding attempt. Contrary to Holland et al., (2014) where suction sampling was used, in this study WBSM were not found to contain high densities of chick food insects (although a different sampling method was used that also collected invertebrates from the ground), therefore, this relationship may reflect the low abundance of chick food resources within one of their preferred habitats. McHugh et al., (2016b) showed that tree sparrow chick diet was affected by the coverage of WBSM present, with chicks found to consume more seed with increasing WBSM area. This increase in seed consumption may impact the total number of chicks surviving to the fledgling stage as plant foods are a poor source of protein compared to invertebrates (Potts, 2012). Other studies showed that consuming less invertebrates led to reduced growth rates and depressed body conditions in yellowhammer chicks (Douglas et al. 2012), slower growth rates and consequently fledgling weights in great Parus major and blue tits Cyanistes caeruleus (Naef- 

(Johnston, 1993).

WBSM was also found to have no significant influence on the other measures of productivity under investigation. Seasonality may be key to the non-significant impact of this habitat. WBSM is primarily a winter habitat and for the majority of the tree sparrow breeding season the mixes sown that year were comprised of bare earth or short vegetation $(0.35 \mathrm{~m} \pm 0.22 \mathrm{~m})$ that would support few invertebrates. Invertebrate abundance increases with vegetation height and structural diversity of a habitat (Eyre and Leifert, 2011; Morris and Lakhani, 1979), therefore WBSM may only provide invertebrates in high abundance when they have had some time to develop.

Despite the high abundance of tree sparrow chick food items in grassland, our measures of

fledging success showed no relationship with the area of this habitat. Grassland area, however, displayed a significant negative relationship with colony size and hatching success per-attempt and likewise Field and Anderson (2004) found grassland was avoided as a foraging habitat. Tree sparrow may avoid grassland as the vegetation structure of many intensively-managed swards (eg vegetation height, density and lack of heterogeneity) renders it unsuitable as a foraging habitat by inhibiting access to the food resources present or by not allowing birds to conduct their vigilance behaviour to avoid predation (Butler et al., 2005; Shaub et al., 2010; Whittingham and Markland, 2002).

Our results showed a positive relationship between oilseed rape and fledgling success in total productivity per pair and per-attempts models and with the per-attempt number of fledglings. 
Winter wheat and oilseed rape are linked through common rotational practices and the high multi-colinearity of these two variables led to the exclusion of winter wheat from our models. The positive effect of oilseed rape on fledgling success implies that crop type could be a central driver of foraging habitat selection, and its relationship with winter wheat suggests that habitat use may be dependent on the landscape context of farms as has been shown in other taxa (e.g. Winqvist et al., 2011). Oilseed rape was also found to contain one of the highest levels of chick-food. This has also been reported in Western Poland, where the mean biomass of insects populating oilseed rape was higher than either spring or winter cereals (Karg and Ryszkowski, 1996). Additionally, Perkins et al., (2007) showed in a seed food preference experiment that oily seeds such as brassicas are exploited by tree sparrow and it is possible that oilseed rape seeds may play an important role in the diet of older chicks because they are small and therefore easy for chicks to handle, in addition to being high in energy (Jones and Earle, 1966; Duke, 1983; Diaz, 1990). Ripening oilseed rape seeds are also know to be important in diet of other granivorous birds i.e. linnet, reed bunting and turtle dove (Gruar et al, 2006).

Fledgling success was also positively related to the proportion of boundary habitat present, tree sparrows have previously been recorded collecting Lepidoptera larva and aphids by searching shrub leaves (Summer-Smith, 1995). A negative relationship was recorded between woodland area and: 1 . total eggs in our total productivity model, 2. Per-attempt hatching success, 3. The number of fledglings per-attempt and 4. per-attempt fledging success. This may due to the association of tree sparrows with open habitats such as farmland (Field and Anderson, 2004; Field et al., 2008). 
Contrary to Svensson (2006) we found no significant relationship between population density and breeding success. We expect that population density is more likely to limit tree sparrow productivity where competition for nest boxes is high, as found by Svensson (2006). In his study, $67 \%$ of boxes were occupied compared to our $39.54 \%$ and $41.06 \%$ occupancy rates in 2013 and 2014 respectively. WBSM was negatively related to several measures of breeding success and the lack of a population density impact on our results implies that WBSM is influencing settlement patterns, attracting birds in winter which then stay in these areas to breed if boxes are nearby. Provisions of over-winter food may, therefore, have removed one limiting factor for this species (overwinter survival), only for it to be replaced by another, this is perhaps evidenced by the fact that the colonies were still growing. Future schemes must ensure that a package of measures are provided (i.e. winter seed food and invertebrate-rich habitat) around nest boxes if colonies are to prosper.

\section{Conclusions}

The results of this study suggest that placing AES habitats which provide an abundance of chick-food invertebrates within the summer foraging range of occupied nest boxes benefits the breeding performance of tree sparrows. The association of large tree sparrow colonies with WBSM was not surprising as this habitat is designed to provide seed for granivorous species during the winter (Hancock and Wilson, 2003) and tree sparrows are relatively sedentary. The implications of reduced fledging success in relation to WBSM is an important aspect of tree sparrow conservation that needs to be addressed and highlights the importance

416 of providing a package of AES measures that deliver the year-round requirements of target, declining bird species on farms. More specifically, we have demonstrated the need to provide 
suitable invertebrate-rich AES options close to (and certainly within the foraging range of) suitable nesting habitats for birds that provision their nestlings primarily on invertebrates.

\section{Acknowledgements}

Thank you to the farmers who allowed us access to their land to conduct fieldwork and to the

North Wiltshire Ringing Group for their assistance in the field. We are also grateful to three anonymous reviewers for their suggestions and comments. This work was supported by a BBSRC case studentship awarded to Imperial College London with support from the Game and Wildlife Conservation Trust [grant number BB/F017324/1]. Additional funding was provided by Natural England's Evidence Programme.

\section{References}

Aebischer, N.J., Wheatley, C.J., Rose, H.R., 2014. Factors associated with shooting accuracy and wounding rate of four managed wild deer species in the UK, based on anonymous field records from deer stalkers. PloS one. 9, e109698.http://dx.doi.org/10.1371/journal.pone.0109698

AONB, 2014. The North Wessex Downs Area of Outstanding Natural Beauty. Management Plan 2014-2019. http://www.northwessexdowns.org.uk/uploads/docs/manplan/North\%20Wessex\%20Downs\% 20AONB\%20Management\%20Plan\%202014-19\%20for\%20WEB.pdf (accessed 08.12.16).

439

Askins, R. A., 1999. History of grassland birds in eastern North America. Studies in Avian 
Bradbury, R.B., Stoate, C., 2000. The Ecology of Yellowhammers Emberiza citrinella on lowland farmland, in: NJ (Ed.), Ecology and Conservation of Lowland Farmland Birds. BOU, pp. 165-172.

Brickle, N.W., Harper, D.G.C., 2000. Habitat use by Corn Buntings Miliaria calandra in winter and summer, in: Aebischer, N.J., Evans, A.D., Grice, P. V, Vickery, J.A. (Eds.), Ecology and Consevation of Lowland Farmland Birds: Proceedings of the 1999 British Ornithologists' Union Spring Conference, University of Southampton, UK. British Ornithological Union, Peterborough, UK, 156-164.

Brickle, N.W., Harper, D.G.C., Aebischer, N.J., Cockayne, S.H., 2000. Effects of agricultural intensification on the breeding success of corn buntings Miliaria calandra. J. Appl. Ecol. 37, 742-756. http://dx.doi.org/10.1046/j.1365-2664.2000.00542.x

Bright, J.A., Morris, A.J., Field, R.H., Cooke, A.I., Grice, P.V., Walker, L.K., Fern, J. Peach, W.J., 2015. Higher-tier agri-environment scheme enhances breeding densities of some priority farmland birds in England. Agric. Ecosyst. Environ. 203, 69-79.

https://doi.org/10.1016/j.agee.2015.01.021

BTO. 2015. Tree Sparrow Passer montanus. URL:

http://blx1.bto.org/birdtrends/species.jsp?year=2014\&s=tresp

Burgess, M. D., Bright, J. A., Morris, A. J., Field, R. H., Grice, P. V., Cooke, A. I., \& Peach, W. 2015. Influence of agri-environment scheme options on territory settlement by Yellowhammer (Emberiza citronella) and Corn Bunting (Emberiza calandra). J. Ornithology. 156(1), 153-163. https:// doi:10.1007/s10336-014-1113-1

Butler, S.J., Whittingham, M.J., Quinn, J.L., Cresswell, W., 2005. Quantifying the interaction between food density and habitat structure in determining patch selection. Anim. Behav. 69, 337-343. http://dx.doi.org/10.1016/j.anbehav.2004.06.006

Crawley, M.J. 2012. The R Book. John Wiley \& Sons. Chichester, England.

Davey, C.M., Vickery, J.A., Boatman, N.D., Chamberlain, D.E., Parry, H.R., Siriwardena, G.M., 2010a. Assessing the impact of Entry Level Stewardship on lowland farmland birds in England. Ibis.152, 459-474. http://dx.doi.org/10.1111/j.1474-919X.2009.01001.x

Davey, C.M., Vickery, J.A., Boatman, N.D., Chamberlain, D.E., Parry, H.R., Siriwardena, G.M., 2010b. Regional variation in the efficacy of Entry Level Stewardship in England. Agric. Ecosyst. Environ. 139, 121-128. http://dx.doi.org/10.1016/j.agee.2010.07.008 
Deckert, G., 1962. Zur Ethologie des Feldsperlings (Passer montanus L.). J. Ornithol. 103, 428-486. http://dx.doi.org/10.1007/BF01676606

Diaz, M., 1996. Food choice by seed- eating birds in relation to seed chemistry. Comp. Biochem. Phys. A. 113:239-246. https://doi.org/10.1016/0300-9629(95)02093-4

Donald, P. F., Sanderson, F. J., Burfield, I. J., Van Bommel, F. P., 2006. Further evidence of continent-wide impacts of agricultural intensification on European farmland birds, 1990 2000. Agric. Ecosyst. Environ. 116 (3), 189-196. https://doi.org/10.1016/j.agee.2006.02.007

Duke, J.A., 1983. Handbook of Energy Crops. Purdue University, West Lafayette, USA.

Douglas, D.J.T., Moreby, S.J., Benton, T.G., 2012. Provisioning with cereal grain depresses the body condition of insectivorous Yellowhammer Emberiza citrinella nestlings. Bird Study. 59, 105-109. http://dx.doi.org/10.1080/00063657.2011.636797

Douglas, D.J.T., Vickery, J.A., Benton, T.G., 2009. Improving the value of field margins as foraging habitat for farmland birds. J. Appl. Ecol. 46, 353-362.

http://dx.doi.org/10.1111/j.1365-2664.2009.01613.x

Eyre, M.D., Leifert, C., 2011. Crop and field boundary influences on the activity of a wide range of beneficial invertebrate groups on a split conventional/organic farm in northern England. Bull. Entomol. Res. 101, 135-44. http://dx.doi.org/10.1017/S0007485310000398

Field, R.H., Anderson, G.Q.A., 2004. Habitat use by breeding Tree Sparrows Passer montanus. Ibis. 146, 60-68. http://dx.doi.org/10.1111/j.1474-919X.2004.00356.x

Field, R. H., Anderson, G. Q., Gruar, D. J., 2008. Land-use correlates of breeding performance and diet in Tree Sparrows Passer montanus. Bird Study. 55(3), 280-289. $\underline{\text { http://dx.doi.org/10.1080/00063650809461533 }}$

\section{Software, 8(15), 1-27.}

Fox, J. 2003. Effect Displays in R for Generalised Linear Models. Journal of Statistical

Gillings, S., Newson, S.E., Noble, D.G., Vickery, J.A., 2005. Winter availability of cereal stubbles attracts declining farmland birds and positively influences breeding population 
trends. Proceedings. Biological sciences / The Royal Society. 272, 733-9.

http://dx.doi.org/10.1098/rspb.2004.3010

Gilroy, J.J., Anderson, G.Q., Grice, P. V., Vickery, J. A., Watts, P.N., Sutherland, W.J., 2009. Foraging habitat selection, diet and nestling condition in Yellow Wagtails Motacilla flava breeding on arable farmland. Bird Study. 56, 221-232.

http://dx.doi.org/10.1080/00063650902792080

Gruar, D., Barritt, D., Peach, W.J., 2006. Summer utilization of Oilseed Rape by Reed Buntings Emberiza schoeniclus and other farmland birds. Bird Study. 53, 47-54. http://dx.doi.org/10.1080/00063650609461415

Hart, J.D., Milsom, T.P., Fisher, G., Wilkins, V., Moreby, S.J., Murray, A.W.A., Robertson, P.A., 2006. The relationship between yellowhammer breeding performance, arthropod abundance and insecticide applications on arable farmland. J. Anim. Ecol. 43, 81-91. http://dx.doi.org/10.1111/j.1365-2664.2005.01103.x

Hole, D. G., Whittingham, M.J., Bradbury, R.B., Anderson, G.Q.A., Lee, P.L.M., Wilson, J.D. \& Krebs, J.R., 2002. Widespread local house-sparrow extinctions. Nature. 418, 931-932. http://dx.doi.org/10.1038/418931a

Holland, J.M., Hutchison, M.A.S., Smith, B., Aebischer, N.J., 2006. A review of invertebrates and seed-bearing plants as food for farmland birds in Europe. Ann. Appl. Biol.148, 49-71. http://dx.doi.org/10.1111/j.1744-7348.2006.00039.x

Holland, J.M., Storkey, J., Lutman, P.J.W., Birkett, T.C., Simper, J., Aebischer, N.J., 2014. Utilisation of agri-environment scheme habitats to enhance invertebrate ecosystem service providers. Agric. Ecosyst. Environ. 183, 103-

109.http://dx.doi.org/10.1016/j.agee.2013.10.025

Ieno, E.N., Zuur, A.F., 2015. A beginner's guide to Data Exploration and Visualisation with R. Highland Statistics. Newburgh, United Kingdom.

Johnston, R.D., 1993. Effects of diet quality on the nestling growth of a wild insectivorous passerine, the house martin Delichon urbica. Functl. Ecol. 7, 255-266.

http://dx.doi.org/10.2307/2390203

Jones, Q., Earle, F.R., 1966. Chemical analyses of seeds II: oil and protein content of 759 species. Econ. Bot. 20: 127-155. http://dx.doi.org/10.1007/BF02904010 
564 Karg, J., Ryszkowski, L., 1996. Animals in arable land. In Dynamics of an

565 agricultural landscape. Ryszokowski, L., French, N., Kedziora A. (Eds.), 138-

566172.

567

568 Kleijn, D., Berendse, F., Smit, R., Gilissen, N. 2001. Agri-environment schemes do not

569 effectively protect biodiversity in Dutch agricultural landscapes. Nature. 413(6857), 723-725.

570 http://dx.doi.org/10.1038/35099540

571

572

Lack, P.C., 1992. Birds on Lowland Farmland. HMSO, London

573

574

575

Marshall, E. J. P., Moonen, A. C. 2002. Field margins in northern Europe: their functions and interactions with agriculture. Agric. Ecosyst. Environ. 89(1), 5-21.

576

https://doi.org/10.1016/S0167-8809(01)00315-2

577

578

Matson, P. A., Parton, W. J., Power, A. G., Swift, M. J., 1997. Agricultural intensification

579

and ecosystem properties. Science. 277(5325), 504-509. DOI: 10.1126/science.277.5325.504

580

581

582

583

584

McHugh, N.M., Goodwin, C.E., Hughes, S., Leather, S.R., Holland, J.M. 2016a. Agrienvironment scheme habitat preferences of Yellowhammer Emberiza citrinella on English farmland. Acta Ornithol. 51(2), 199-209.

http://dx.doi.org/10.3161/00016454AO2016.51.2.006

585

586

587

McHugh, N.M., Prior, M., Leather, S.R., Holland, J.M., 2016b. The diet of Eurasian Tree

588

Sparrow Passer montanus nestling in relation to agri-environment scheme habitats. Bird Study. 63, 279-283. http://dx.doi.org/10.1080/00063657.2016.1182964

589

590

591

Morris, M.G., Lakhani, K.H. 1979. Responses of grassland invertebrates to management by

592 cutting. I. Species diversity of Hemiptera [in Great Britain]. J. Appl. Ecol. 20, 157-177.

http://dx.doi.org/10.2307/2402730

593

Morris, A.J., Whittingham, M.J., Bradbury, R.B., Wilson, J.D., Kyrkos, A., Buckingham, 595 D.L., Evans, A.D., 2001. Foraging habitat selection by yellowhammers (Emberiza citrinella) 596 nesting in agriculturally contrasting regions in lowland England. Biol. Conserv. 101, 197597 210. http://dx.doi.org/10.1016/S0006-3207(01)00067-2

598

Murphy, M. T., 2003. Avian population trends within the evolving agricultural landscape of 600 eastern and central United States. The Auk. 120(1), 20-34. 
Naef-Daenzer, B., Keller, L.F., 1999. The foraging performance of great and blue tits (Parus major and P. caeruleus) in relation to caterpillar development and its consequences for nestling growth and fledging weight. J. Anim. Ecol. 68: 708-718.

Natural England., 2013a. Environmental Stewardship Handbook. Entry Level Stewardship.

Natural England., 2013b. Environmental Stewardship Handbook. Higher Level Stewardship.

Fourth Edition. Natural England Report.

Newton, I., 2004. The recent declines of farmland bird populations in Britain: an appraisal of causal factors and conservation actions. Ibis. 146, 579-600.

Pärn, H., Ringsby, T.H., Jensen, H., Sæther, B., 2011. Spatial heterogeneity in the effects of climate and density-dependence on dispersal in a house sparrow metapopulation. Proc. R.

Soc. B. 279, 144-152. http://dx.doi.org/10.1098/rspb.2011.0673.

Potts, G.R., 2012. Partridges: Countryside Barometer. Collins, London, England.

Princé, K., Moussus, J.P., Jiguet. F., 2012. Mixed effectiveness of French agri-environment

R Core Development Team. (2014) R version 3.0.2: A Language and Environment for

Perkins, A.J., Anderson, G.Q.A., Wilson, J.D., 2007. Seed food preferences of granivorous farmland passerines. Bird Study. 54(1), 46-53.

http://dx.doi.org/10.1080/000636500709461455

\section{Statistical Computing. Austria: R Foundation for Statistical Computing.}

Ringsby T. H., Sæther B.-E., Tufto J., Jensen H., Solberg E. J., 2002. Asynchronous spatiotemporal demography of a house sparrow metapopulation in a correlated environment. Ecology. 83, 561-569. doi:10.1890/00129658(2002)083[0561:ASDOAH]2.0.CO;2

Robinson, R.A., Wilson, J.D., Crick, H.Q.P., 2002. The importance of arable habitat for farmland birds in grassland landscapes. J. Appl. Ecol. 38, 1059-1069. 
641 Schaub, M., Martinez, N., Tagmann-Ioset, A., Weisshaupt, N., Maurer, M. L., Reichlin, T. S., 642 Abadi, F., Zinden, N., Jenni, L., Arlettaz, R., 2010. Patches of Bare Ground as a Staple

643 Commodity for Declining Ground-Foraging Insectivorous Farmland Birds. PLoS ONE,

644 5(10), e13115. https://doi.org/10.1371/journal.pone.0013115

645 Siriwardena, G.M., Stevens, D.K., Anderson, G.Q.A., Vickery, J.A., Calbrade, N.A., Dodd, 646 S., 2007. The effect of supplementary winter seed food on breeding populations of farmland 647 birds: evidence from two largescale experiments. J. Appl. Ecol. 44: 920-932.

648 http://dx.doi.org/10.1111/j.1365-2664.2007.01339.x

Sotherton, N. W., Self, M. J. 2000. Changes in plant and arthropod biodiversity on lowland farmland: an overview. Ecology and conservation of lowland farmland birds, 26-35.

Southwood, R., 1987. Ecological methods: With particular reference to the study of insect populations. Springer, Berlin, Germany.

Summers-Smith, J.D., 1995. The Tree Sparrow. J.D. Summers-Smith, Guisborough, United

Kingdom.

Svensson, M., 2006. Embryonic Mortality and Sex Ratios in the Tree Sparrow. University of 660 Uppsala.

Tscharntke, T., Klein, A. M., Kruess, A., Steffan-Dewenter, I., Thies, C., 2005. Landscape perspectives on agricultural intensification and biodiversity-ecosystem service management. Ecol. Lett. 8(8), 857-874. http://dx.doi.org/10.1111/j.1461-0248.2005.00782.x

Vickery, J.A., Carter, N., Fuller, R.J., 2002. The potential value of managed cereal field margins as foraging habitats for farmland birds in the UK. Agric. Ecosyst. Environ. 89, 4152. http://dx.doi.org/10.1016/S0167-8809(01)00317-6

Vorisek, P., 2005. Population trends of European common birds, 2005 update. Internet publication, European Bird Census Council: http://www. ebcc. info. 
681 Wickham, H., 2009. ggplot2: Elegant Graphics for Data Analysis. Springer-Verlag, New 682 York, USA.

684 Wilson, J.D., 2001. Foraging habitat selection by skylarks Alauda arvensis on lowland 685 farmland during the nestling period. In: Donald, P.F., Vickery, J.A. (Eds) Ecology and 686 Conservation of Skylarks Alauda arvensis, RSPB, Sandy, 91- 101.

688 Winqvist, C., Bengtsson, J., Aavik, T., Berendse, F., Clement, L.W., Eggers, S., 689 Fischer, C., Flohre, A., Geiger, F., Liira, J., Pärt, T., Thies, C., Tscharntke, T., 690 Weisser, W.W. Bommarco, R.. 2011. Mixed effects of organic farming and 691 landscape complexity on farmland biodiversity and biological control potential 692 across Europe. J. Appl. Ecol. 48, 570-579.

693

694 Zhang, S., Zheng, G., 2010. Effect of urbanization on the abundance and distribution of Tree 695 Sparrows (Passer montanus) in Beijing. Chinese Birds. 1, 188-197.

696 http://dx.doi.org/10.5122/cbirds.2010.0012

Zuur, A.F., Ieno, E.N., Elphick, C.S., 2010. A protocol for data exploration to avoid common 699 statistical problems. Methods Ecol. Evol. 1, 3-14. http://dx.doi.org/10.1111/j.2041-

700 210X.2009.00001.x 


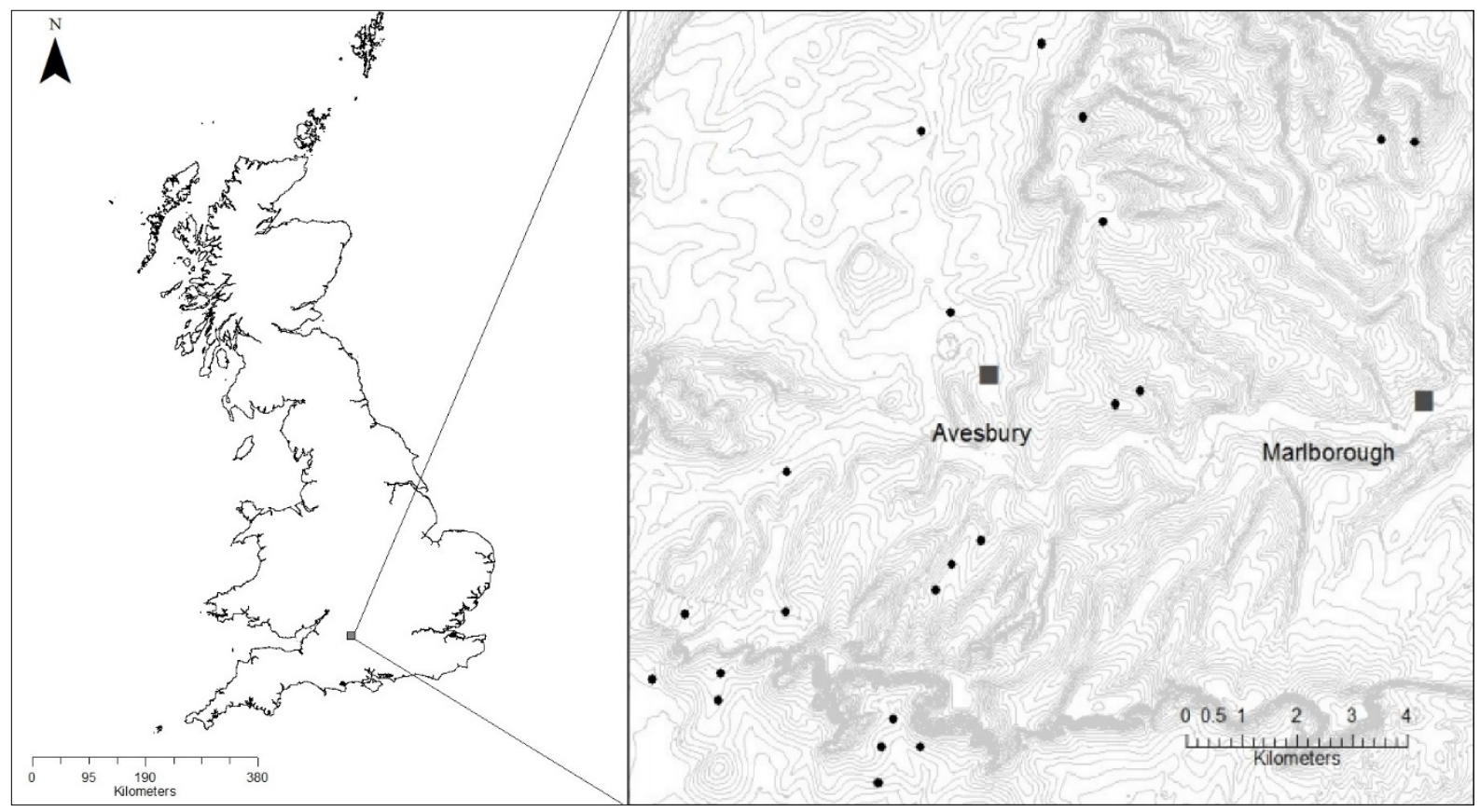

Figure 1. Map showing (a) the location of the sampling region in Southern England and (b) the tree sparrow colony locations within this region relative to two settlements. 
A

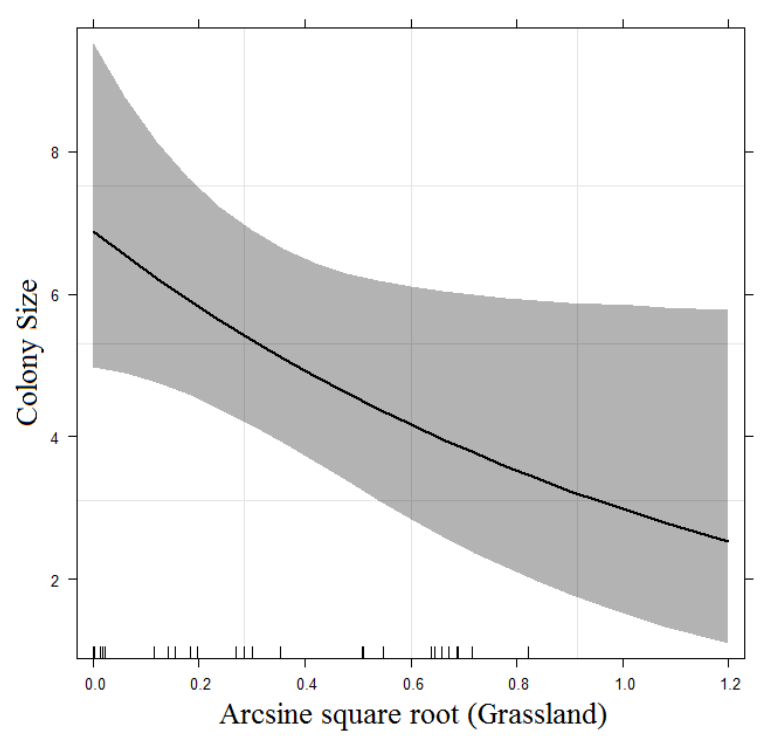

B

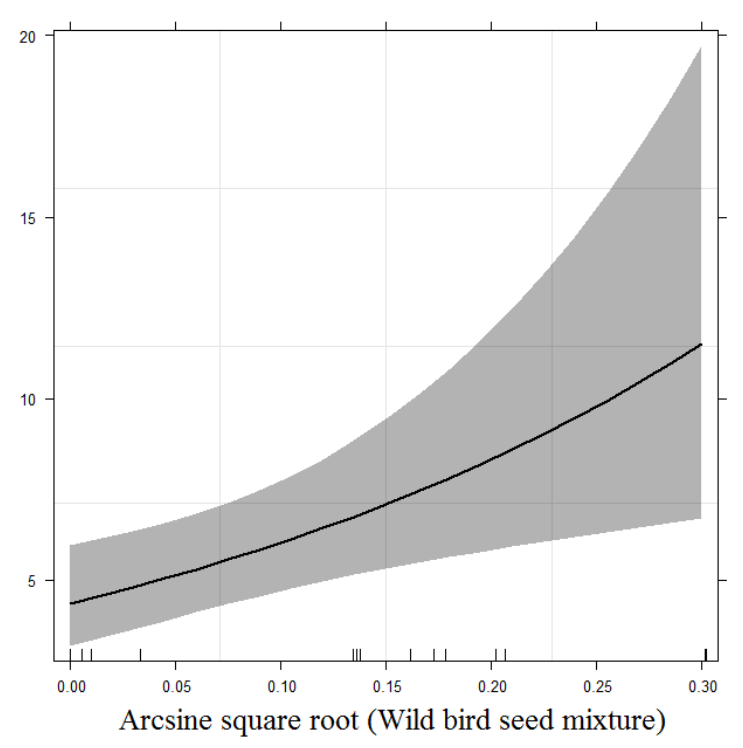

Figure 2. Predicted values for colony size relative to two significant variables (Table 2) chosen by backward stepwise deletion from the full GLM: a) grassland and b) wild bird seed mixture. For each covariate displayed probabilities are adjusted relative to the effects of the other variables modelled. A 95\% confidence interval is drawn around the estimated effect. 
A

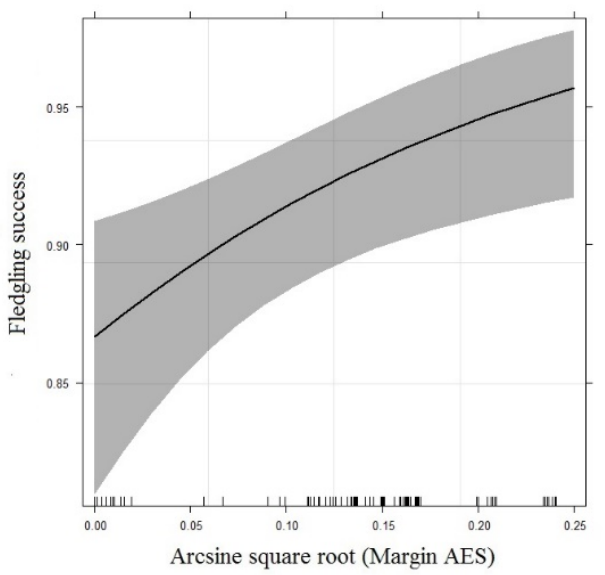

B

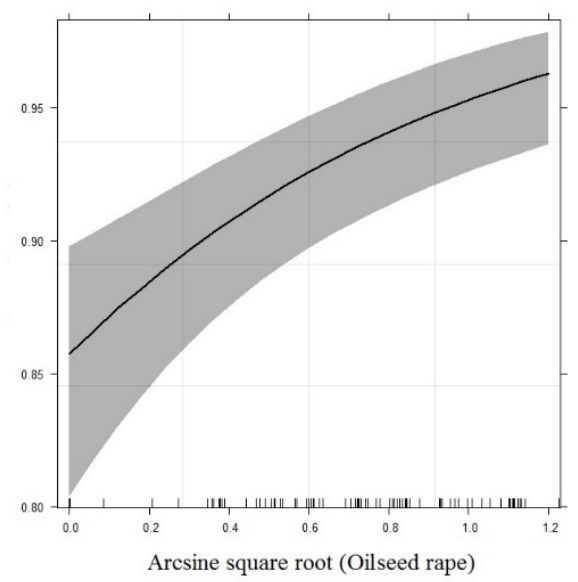

c

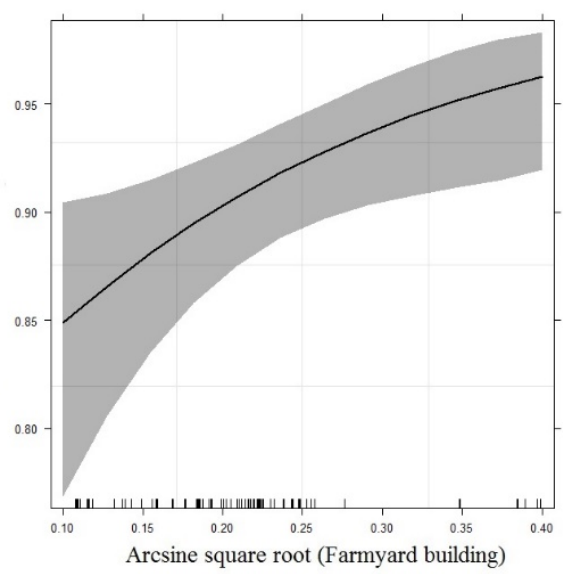

D

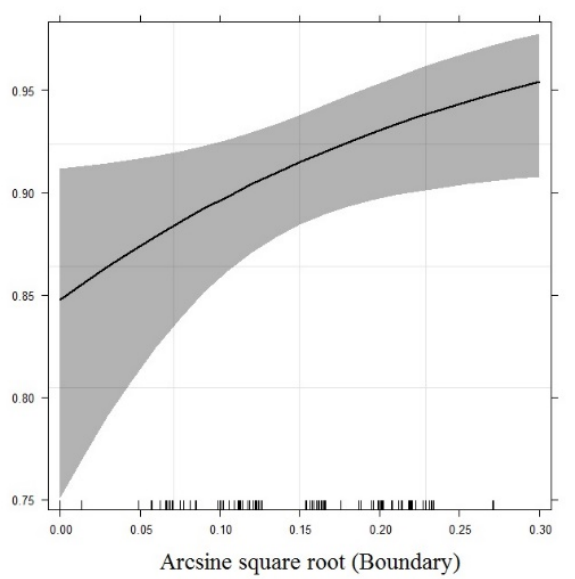

Figure 3. Predicted values for fledgling success per pair relative to four significant variables (Table 2) chosen by backward stepwise deletion from the full GLMM: a) margin AES, b) oilseed rape, c) farmyard building and d) boundary. For each covariate displayed probabilities are adjusted relative to the effects of the other variables modelled. A $95 \%$ confidence interval is drawn around the estimated effect. 


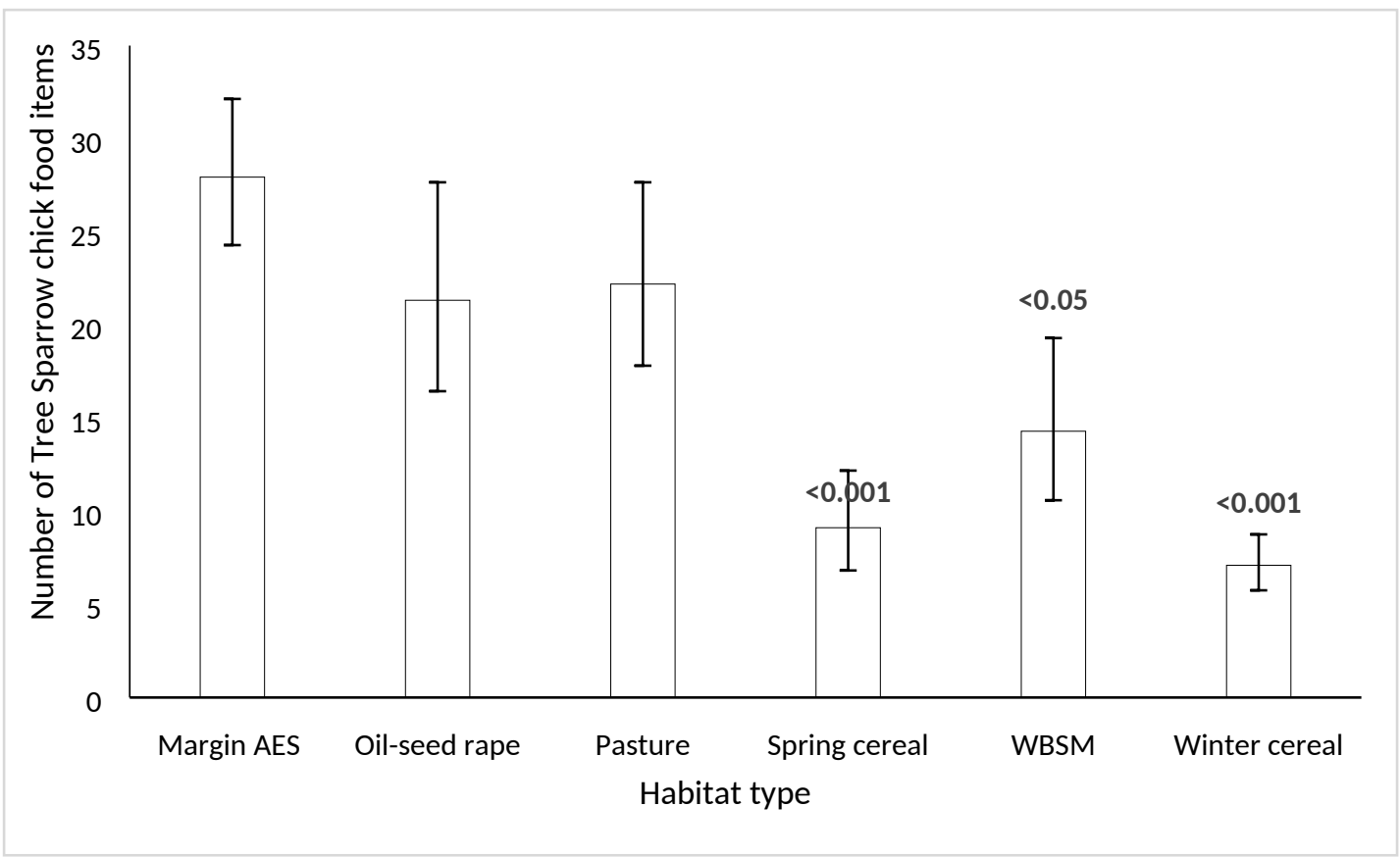

Figure 4. The number of tree sparrow chick food items (mean $\pm \mathrm{SE}$ ) recorded in pooled habitat types. The mean and standard errors of model estimates were back transformed for graphical representation. P-values refer to significant deviations from the reference variable, margin AES. 
Table 1. Structure of GLMs and GLMMs used for analysis, fixed effects were included in models simultaneously. Habitat area measurements refer to Appendix 1 "habitat category" codes and represent habitats present within the $200 \mathrm{~m}$ adult foraging ranges from nest boxes.

\begin{tabular}{|c|c|c|c|c|c|}
\hline & $\begin{array}{l}\text { Model } \\
\text { type }\end{array}$ & Response & $\begin{array}{l}\text { Error structure/ } \\
\text { link function }\end{array}$ & Fixed Effects & Random effects \\
\hline Colony size & GLM & Colony size & Quasipoisson/log & $\begin{array}{l}\text { Mean permanent habitat category area } \\
\text { measurements, year }\end{array}$ & N/A \\
\hline \multirow{5}{*}{$\begin{array}{l}\text { Total } \\
\text { productivity } \\
\text { per pair }\end{array}$} & GLMM & Total eggs & Poisson/log & Habitat category area measurements & Colony, Nest box/Year \\
\hline & GLMM & Hatching success & Binomial/logit & Habitat category area measurements & Colony, Nest box/Year \\
\hline & GLMM & Total fledglings & Poisson/log & Habitat category area measurements & Colony, Nest box/Year \\
\hline & GLMM & Fledgling success & Binomial $/ \operatorname{logit}$ & Habitat category area measurements & Colony, Nest box/Year \\
\hline & GLMM & Number of attempts & Poisson/log & Habitat category area measurements & Colony, Nest box/Year \\
\hline \multirow{4}{*}{$\begin{array}{l}\text { Per-attempt } \\
\text { productivity }\end{array}$} & GLMM & Clutch size & Poisson/log & Habitat category area measurements, brood & Colony, Nest box/ Year \\
\hline & GLMM & Hatching Success & Binomial/logit & Habitat category area measurements, brood & Colony, Nest box/ Year \\
\hline & GLMM & Fledging's per brood & Poisson/log & Habitat category area measurements, brood & Colony, Nest box/Year \\
\hline & GLMM & Fledging success & Binomial/logit & Habitat category area measurements, brood & Colony, Nest box//Year \\
\hline $\begin{array}{l}\text { Chick Food } \\
\text { abundance }\end{array}$ & GLMM & Chick food & Poisson/log & Habitat category & Colony \\
\hline \multirow[t]{4}{*}{ Density dependence } & GLM & $\begin{array}{l}\text { Mean clutch size per } \\
\text { colony }\end{array}$ & Poisson/log & Colony size, year, brood & N/A \\
\hline & GLM & $\begin{array}{l}\text { Mean hatching } \\
\text { success per colony }\end{array}$ & Quasibinomial/logit & Colony size, year, brood & N/A \\
\hline & GLM & $\begin{array}{l}\text { Mean number of } \\
\text { fledglings per colony }\end{array}$ & Poisson/log & Colony size, year, brood & N/A \\
\hline & GLM & $\begin{array}{l}\text { Mean fledgling } \\
\text { success per colony }\end{array}$ & Quasibinomial/logit & Colony size, year, brood & N/A \\
\hline
\end{tabular}


Table 2. Estimated parameter and $p$ values for each fixed effect present in MAMs relating to colony size, total productivity per pair of sparrows and per-attempt productivity. Null models are not presented.

\begin{tabular}{|c|c|c|c|c|c|}
\hline & Model & Fixed Effects & Estimate \pm SE & Z-value & $\mathbf{P}$ \\
\hline \multirow[t]{3}{*}{ Colony size } & \multirow[t]{3}{*}{ Colony size } & Intercept & $1.76 \pm 0.19$ & 6.43 & $<0.001$ \\
\hline & & Wild bird seed mixture & $3.22 \pm 1.10$ & 2.92 & $<0.01$ \\
\hline & & Grassland & $-0.84 \pm 0.41$ & -2.02 & $<0.05$ \\
\hline \multirow{15}{*}{$\begin{array}{l}\text { Total } \\
\text { productivity } \\
\text { per pair }\end{array}$} & \multirow[t]{2}{*}{ Total eggs } & Intercept & $2.42 \pm 0.04$ & 58.24 & $<0.001$ \\
\hline & & Woodland & $-0.93 \pm 0.32$ & -2.91 & $<0.01$ \\
\hline & \multirow{6}{*}{$\begin{array}{l}\text { Hatching } \\
\text { success }\end{array}$} & Intercept & $1.78 \pm 0.42$ & 4,22 & $<0.001$ \\
\hline & & Margin AES & $-3.81 \pm 1.69$ & -2.26 & $<0.05$ \\
\hline & & Wild bird seed mixture & $-6.72 \pm 1.76$ & -3.82 & $<0.001$ \\
\hline & & Farmyard building & $6.32 \pm 2.14$ & 2.95 & $<0.01$ \\
\hline & & Grassland & $-1.16 \pm 0.53$ & -2.21 & $<0.05$ \\
\hline & & Woodland & $-3.63 \pm 1.78$ & -2.04 & $<0.05$ \\
\hline & \multirow{5}{*}{$\begin{array}{l}\text { Fledgling } \\
\text { success }\end{array}$} & Intercept & $-0.39 \pm 0.56$ & -0.71 & 0.47 \\
\hline & & Margin AES & $4.91 \pm 1.79$ & 2.74 & $<0.01$ \\
\hline & & Oilseed rape & $1.22 \pm 0.28$ & 4.39 & $<0.001$ \\
\hline & & Farmyard building & $5.09 \pm 1.97$ & 2.59 & $<0.01$ \\
\hline & & Boundary & $4.38 \pm 2.01$ & 2.18 & $<0.05$ \\
\hline & \multirow{2}{*}{$\begin{array}{l}\text { Number of } \\
\text { Broods }\end{array}$} & Intercept & $0.69 \pm 0.06$ & 11.45 & $<0.001$ \\
\hline & & Woodland & $-0.60 \pm 0.49$ & -1.24 & 0.216 \\
\hline \multirow{23}{*}{$\begin{array}{l}\text { Per-attempt } \\
\text { productivity }\end{array}$} & \multirow{8}{*}{$\begin{array}{l}\text { Hatching } \\
\text { success }\end{array}$} & Intercept & $1.62 \pm 0.44$ & 3.69 & $<0.001$ \\
\hline & & Margin AES & $-3.88 \pm 1.73$ & -2.25 & $<0.05$ \\
\hline & & Wild bird seed mixture & $-6.75 \pm 1.80$ & -3.76 & $<0.001$ \\
\hline & & Farmyard building & $6.55 \pm 2.20$ & 2.98 & $<0.01$ \\
\hline & & Grassland & $-1.18 \pm 0.56$ & -2.11 & $<0.05$ \\
\hline & & Woodland & $-3.70 \pm 1.82$ & -2.04 & $<0.05$ \\
\hline & & $\operatorname{Brood}\left(2^{\text {nd }}\right)$ & $0.57 \pm 0.15$ & 3.86 & $<0.001$ \\
\hline & & $\operatorname{Brood}\left(3^{\text {rd }}\right)$ & $-0.12 \pm 0.16$ & -0.76 & 0.44 \\
\hline & \multirow{7}{*}{$\begin{array}{l}\text { Number of } \\
\text { fledglings }\end{array}$} & Intercept & $1.08 \pm 0.10$ & 11.14 & $<0.001$ \\
\hline & & Wild bird seed mixture & $-1.08 \pm 0.34$ & -3.22 & $<0.001$ \\
\hline & & Oilseed rape & $0.15 \pm 0.06$ & 2.62 & $<0.001$ \\
\hline & & Farmyard buildings & $1.22 \pm 0.43$ & 2.81 & $<0.001$ \\
\hline & & Woodland & $-0.85 \pm 0.38$ & -2.11 & $<0.01$ \\
\hline & & $\operatorname{Brood}\left(2^{\text {nd }}\right)$ & $0.22 \pm 0.05$ & 3.96 & $<0.001$ \\
\hline & & Brood $\left(3^{\text {rd }}\right)$ & $0.09 \pm 0.07$ & 1.31 & $<\mathbf{0 . 0 1}$ \\
\hline & \multirow{8}{*}{$\begin{array}{l}\text { Fledgling } \\
\text { success }\end{array}$} & Intercept & $-0.90 \pm 0.57$ & -1.56 & 0.12 \\
\hline & & Margin AES & $5.12 \pm 1.78$ & 2.89 & $<0.05$ \\
\hline & & Oilseed rape & $1.09 \pm 0.26$ & 4.16 & $<0.001$ \\
\hline & & Farmyard buildings & $7.12 \pm 2.17$ & 3.29 & $<0.05$ \\
\hline & & Boundary & $3.96 \pm 1.99$ & 1.99 & $<0.05$ \\
\hline & & Woodland & $-3.28 \pm 1.65$ & -1.99 & $<0.05$ \\
\hline & & $\operatorname{Brood}\left(2^{\text {nd }}\right)$ & $0.94 \pm 0.19$ & 5.04 & $<0.001$ \\
\hline & & Brood $\left(3^{\text {rd }}\right)$ & $0.45 \pm 0.20$ & 2.16 & $<0.05$ \\
\hline
\end{tabular}




\section{Appendix A}

Table A1. Pooled and component habitat types present within foraging distance $(200 \mathrm{~m})$ of tree sparrow nest boxes. The habitat categories are explanatory variables in our colony size, total productivity per-pair and per-attempt models.

\begin{tabular}{|c|c|c|}
\hline Habitat category & Component & Mean \pm SE \\
\hline Boundary & $\begin{array}{l}\text { Hedges, tree line, grassy verges, } \\
\text { scrub (young plantation or } \\
\text { deciduous scrub) }\end{array}$ & $3120.59 \pm 151.91 \mathrm{~m}^{2}$ \\
\hline Farmyard building & Roads, tracks, farm buildings & $6642.23 \pm 292.68 \mathrm{~m}^{2}$ \\
\hline Grassland & $\begin{array}{l}\text { Permanent and temporary } \\
\text { grassland }\end{array}$ & $15131.58 \pm 1180.56 \mathrm{~m}^{2}$ \\
\hline Margin AES & $\begin{array}{l}2 \mathrm{~m}, 4 \mathrm{~m} \text { and } 6 \mathrm{~m} \text { grass buffer strips, } \\
\text { floristically enhanced margins, } \\
\text { pollen and nectar margins, } \\
\text { uncropped field corners }\end{array}$ & $1922.29 \pm 99.608 \mathrm{~m}^{2}$ \\
\hline Oil-seed rape & Oil-seed rape & $38676.00 \pm 2172.01 \mathrm{~m}^{2}$ \\
\hline Other arable & Spring beans, maize & $3514.18 \pm 595.45 \mathrm{~m}^{2}$ \\
\hline Spring cereal & Spring wheat, spring barley & $7441.27 \pm 1141.13 \mathrm{~m}^{2}$ \\
\hline Water & Lakes, ponds, streams and ditches & $70.61 \pm 16.10 \mathrm{~m}^{2}$ \\
\hline $\begin{array}{l}\text { Wild bird seed } \\
\text { mixture }\end{array}$ & Wild bird seed & $2424.43 \pm 148.83 \mathrm{~m}^{2}$ \\
\hline Winter cereal & Winter wheat, winter barley & $44946.59 \pm 1986.38 \mathrm{~m}^{2}$ \\
\hline Woodland & $\begin{array}{l}\text { Deciduous and coniferous } \\
\text { woodland }\end{array}$ & $1725.64 \pm 162.99 \mathrm{~m}^{2}$ \\
\hline
\end{tabular}




\section{Appendix B}

Table B1. Estimated parameter and $p$ values for each fixed effect present in density dependence models for clutch size, hatching success, number of fledglings and fledgling success.

\begin{tabular}{|c|c|c|c|c|}
\hline Model & Fixed Effects & Estimate \pm SE & Z-value & $\mathbf{P}$ \\
\hline \multirow[t]{7}{*}{ Clutch size } & Intercept & $1.17 \pm 0.33$ & 3.61 & $<0.001$ \\
\hline & Colony size & $-0.03 \pm 0.04$ & -0.83 & 0.41 \\
\hline & $\operatorname{Brood}\left(2^{\text {nd }}\right)$ & $0.47 \pm 0.47$ & 1.00 & 0.32 \\
\hline & Brood $\left(3^{\mathrm{rd}}\right)$ & $-0.06 \pm 0.48$ & -0.13 & 0.90 \\
\hline & Year (2014) & $0.12 \pm 0.26$ & 0.47 & 0.64 \\
\hline & Colony size:Brood $\left(2^{\text {nd }}\right)$ & $0.02 \pm 0.06$ & 0.37 & 0.71 \\
\hline & Colony size:Brood (3rd) & $0.04 \pm 0.06$ & 0.66 & 0.51 \\
\hline \multirow{7}{*}{$\begin{array}{l}\text { Hatching } \\
\text { success }\end{array}$} & Intercept & $1.17 \pm 0.33$ & 3.61 & $<0.001$ \\
\hline & Colony size & $-0.03 \pm 0.04$ & 0.81 & 0.41 \\
\hline & $\operatorname{Brood}\left(2^{\text {nd }}\right)$ & $0.47 \pm 0.47$ & 1.00 & 0.32 \\
\hline & $\operatorname{Brood}\left(3^{\text {rd }}\right)$ & $-0.06 \pm 0.49$ & -0.29 & 0.90 \\
\hline & Year (2014) & $0.12 \pm 0.26$ & 0.47 & 0.61 \\
\hline & Colony size:Brood ( $\left.2^{\text {nd }}\right)$ & $0.02 \pm 0.06$ & 0.37 & 0.71 \\
\hline & Colony size:Brood $\left(3^{\text {rd }}\right)$ & $0.04 \pm 0.06$ & 0.66 & 0.51 \\
\hline \multirow{7}{*}{$\begin{array}{l}\text { Number of } \\
\text { fledglings }\end{array}$} & Intercept & $1.12 \pm 0.15$ & 7.72 & $<0.001$ \\
\hline & Colony size & $-0.00 \pm 0.02$ & -0.24 & 0.80 \\
\hline & Brood $\left(2^{\text {nd }}\right)$ & $0.26 \pm 0.18$ & 1.44 & 0.14 \\
\hline & Brood $\left(3^{\mathrm{rd}}\right)$ & $0.12 \pm 0.21$ & 0.58 & 0.56 \\
\hline & Year (2014) & $0.22 \pm 0.10$ & 2.07 & 0.56 \\
\hline & Colony size:Brood (2nd $)$ & $0.00 \pm 0.02$ & 0.02 & 0.99 \\
\hline & Colony size:Brood (3rd) & $0.00 \pm 0.02$ & 0.06 & 0.95 \\
\hline \multirow{7}{*}{$\begin{array}{l}\text { Fledgling } \\
\text { success }\end{array}$} & Intercept & $1.11 \pm 0.34$ & 3.22 & $<0.01$ \\
\hline & Colony size & $-0.01 \pm 0.04$ & -0.34 & 0.74 \\
\hline & $\operatorname{Brood}\left(2^{\text {nd }}\right)$ & $0.69 \pm 0.53$ & 1.30 & 0.19 \\
\hline & Brood $\left(3^{\text {rd }}\right)$ & $0.16 \pm 0.53$ & 0.29 & 0.77 \\
\hline & Year (2014) & $1.11 \pm 0.31$ & 3.62 & $<0.01$ \\
\hline & Colony size:Brood (2nd $)$ & $-0.02 \pm 0.06$ & -0.27 & 0.79 \\
\hline & Colony size:Brood $\left(3^{\text {rd }}\right)$ & $-0.01 \pm 0.06$ & -0.18 & 0.86 \\
\hline
\end{tabular}

